\title{
The Intoxication of Power in George Orwell's Nineteen Eighty Four (1949) and Aldous Huxley's Brave New World (1932)
}

\author{
Hadjer Khatir \\ Research Scholar \\ Amman, Jordan \\ khatir.hadjer@hotmail.fr
}

\begin{abstract}
George Orwell's Nineteen Eighty Four (1949) and Aldous Huxley's Brave New World (1932) stand as two powerful works of art that have emanated from a mere disorder and fragmentation. To put it differently, this works of art have exhaled from a world that has gone through rigorous political transformations and cultural seismology. This is a world that has witnessed an overwhelming dislocation. All those upheavals have brought into being a new life, that is, a reshuffled one. A new life brings forwards a new art. This research, accordingly, attempts toput its focus on two modernist visionary works of art that have enhanced a completely new system of thought and perceived the past, the present, and even the future with an entirely new consciousness. In the worlds of Nineteen Eighty Four and Brave New World, power seems to get beyond of what is supposed to be politically legitimate. Such power has pxedthe way for the emergence of a totalitarian system; I would rather call it a totalitarian virus. This system has emerged with the ultimate purpose of deadening the spirit of individualism, rendering the classes nothing but "docile masses". Accordingly this paper shall analyse how power becomes intoxicating. In other words, it atte mpts to give a keen Picture of how power becomes no longer over things, but rather over men according toNietzsche's philosophical perception of "The Will
\end{abstract}


to Power".

Keywords: Aldous Huxley, George Orwell, N i et z s c he, Totalitarianism, Dystopia, Utopia, Docile Masses.

\section{Introduction}

The first thing that may occur into our minds and would appear entirely dangerous is how the world was really like before power has become the ultimate purpose of man? If we look deeper at every corner of the matter, we will encounter $\$$ many other philosophical questions which in turn are veiled with paradoxes and tremendously complicated clues and hints. Indeed, one main idea may embody these paradoxes is the incredibly developed modern instruments and means of deceit that have successfully attained a total control over the human mind after a long process of scientific and technological progression and ceaseless advancement.

In this paper, I intend to dig deeper into the issue of power, more particularly, the political power that has reached the peak of oligarchy and despotism, and has liquidated the so-called classes into nothing but docile masses that are either controlled by fear and terror (this is the frightful atmosphere that overwhelmed the world of Nineteen Eighty Four) or by a blind pleasure and contentedness (an artificial gratification and gladness enveloping theworld of Brave New World). Indeed, in the worlds of Nineteen Eighty Four and Brave New World, everything starts from rebellion, from a dream "for a golden future time", a time when equality and freedom would prevail among humanity. Definitely, everything begins from a philosophy of an appealing wisdom that has shaken the hearts of its hearers and has drawn for them a beacon of light in their darkest times. Perhaps we should ask ourselves at the first place what does the word "revolution" mean after all? If we take a glimpse at history when 
DOI: https://doi.org/10.24113/ijohmn.v6i1.165

revolutions have takenplace, we come to ask ourselves to what extent those revolutions were successful? Has a revolution really paved the way for a solution? Correspondingly, this paper attempts to foreground a century which begins with a revolution and ends with a hideous affair. It intends to shed light on a vision that has appeared to be utopian, however, factitiously has become dystopian. Nineteen Eighty Four and Brave New World are visionary masterpieces through which George Orwell and Aldous Huxley have foreseen the future from the basis of tumultuous and cataclysmic events that took place in their past and present.

Assuredly, enough has happened in the world that has paved the way for its radical change. That is to say, enough has happened to make the world perhaps what it appears to be today. The industrial revolution, the ceaselessly developing sciences and technologies that have followed it, the two World Wars, the denotation of the atomic bomb as well as the cold war. In fact, each single event manifested itself as a crucial turning point in the history of humanity. All these bloody wars and revolutions that have succeeded each other were awakened by the thrill for power. As the latter has grown tremendously, it has brought into being a whole deterministic political system; a peculiar system that is entirely capable of destroying human values as well as the notion of human nature. The so-called revolutions have not really suggested an authentic solution. They rather have given birth to other forms of dictatorships.

No matter how Nineteen Eighty Four and Brave New World, differ in style and content; they seem to be following a Nietzschean thread to power. For Nietzsche's philosophy is a concrete feature that is linked to dominion. We may, accordingly, realise that these two visionary works have much to say and therefore to convey about where power is leading humanity to. Undeniably, behind the decayed and failed hopes for "a golden future time," there lies the intoxication of power. If we delve into the mysteriousness of these worlds, we will find that the growing docile masses of Nineteen Eighty Four's consciousness of its entirely totalitarian system which I would call a totalitarian virus is extremely bold and apparent. This 
DOI: https://doi.org/10.24113/ijohmn.v6i1.165

virus that holds all sorts of fear and agony appears to penetrate into the profundity of the society and deprive its people from the very essence of their humanity. Nineteen Eighty Four, therefore, stands as an entirely deterministic nightmare; this is a world where power after a long process of destructing the language, the falsification of history, and alteration of human nature reaches the centre that lies above everything. In a world where language is eradicated and history is erased, there is no such a thing as peace, equality and freedom. If not from the roots of these principles that the previous revolutions have arisen and were motivated to fight heart and soul for, upon which real basis would the party endure its system and convince its masses to ensure their fellowship? The answer to this question would run as the following:

WAR IS PEACE FREEDOM IS SLAVERY

\section{IGNORANCE IS STRENGTH}

Whereas in Brave New World, the answer runs as the following:"...COMMUNITY, IDENTITY, STABILITY."

Actually, this is the vision that Huxley has about Totalitarianism in the society of Brave New World which becomes more and more a world where:

everybody happy and no one ever sad or angry, and every one belonging to everyone else, and the boxes where you could see and hear what was happening at the other side of the world, and babies in lovely clean bottles-everything so clean, and no nasty smells, no dirt at all-and people neverlonely, but living together and being so jolly and happy, like the summer dances here in Malpais, but much happier, and the happiness being there everyday, every day. (Huxley 86)

This vision depicts and reflects a flawless happy world. In addition, it seems that technology stands at the centre of this hedonistic world which becomes a sort of doctrine that rules the society. Notably, technological progress is an idea that is rooted among the intellectuals of the twentieth century. It holds the promise of leading humanity towards 
DOI: https://doi.org/10.24113/ijohmn.v6i1.165

boundless prosperity.

From these bold three words...COMMUNITY, IDENTITY, STABILITY which are hung in a sign over the Central London Hatchery and Conditioning Centre, the conditions of an entirely new human life are created. Indeed, these are the words that constitute the slogans of the society; each slogan fuses a double meaning which in turn requires a double thinking of a whole system of thought that claims to be something, but aims to reach something else.If we take for instance the slogan of the society of Brave New World. COMMUNITY means that the people must stand together and work together in order to maximize the greatest happiness for the greatest number of people and this idea and notion of community occurs through the artificially implemented word which is IDENTITY that each person represents in a way or another. If we ponder on the word identity itself, one may notice in a clearnoticeable manner that this word lurks ironically in the society of Brave New World .For the society is already divided into alpha, beta, and gammas. The people are conditioned to be happy with their socalled identity so that never anyone would ever think of rebelling against:"For Gammas, Deltas and Epsilons had been to some extent conditioned to associate corporeal mass with social superiority."(Huxley, Brave New World 43). To emphasize, the idea of rebellion itself does not exist any longer in the dictionary of these people because theyare conditioned to be what they are before they have ever came to existence. The epsilons do not really mind being epsilons or the gammas do not really mind to be gammas and here lies the ruthless position of being totally conditioned simply because these people “don't know what it's like being anything else. We'd mind, of course. But then we've been differently conditioned. Besides, we start with a different heredity.”(Huxley, Brave New World 50)

That is indeed what brings power to the centre of everything. Power, O'Brien in Nineteen Eight Four affirms "is the exact opposite of the stupid hedonistic utopias the old reformers imagines" (Orwell, Nineteen Eighty Four 188). We shall justify why this hopeful 
DOI: https://doi.org/10.24113/ijohmn.v6i1.165

vision towards the future has faded away from the point of view of Nietzsche in order to comprehend more profoundly why all the ideals and values of the revolution have become meaningless. In his book, The Will to Power Nietzsche affirms that "in most cases, to be sure, assurances of peace are merely narcotic" (Nietzsche, The Will to Power 386). We derive, correspondingly, the idea that there is absolutely no such a thing in the life of humanity as the total and concrete existence of pure peace and democratic freedom. Thesame idea can be encapsulated in the world of Nineteen Eighty Four where "no reform or revolution has ever brought equality a millimeter nearer" (Orwell, Nineteen Eighty Four 134).The same thing can be perceived in the society of Brave New World, for no matter how the life in this society in particular seems overwhelmed with cold contentedness and artificial and mechanised happiness, the so-called peace, equality, and freedom are merely illusions. Whether in Nineteen Eighty Four or Brave New World both worlds have established an unquestionable totalitarian system, whether through the intensification of a dreary and dim reality or a happy and pleasurable reality, both worlds seek to reach the same end which Nietzsche in turn accentuates on: "every possible kind of limitation, one sidedness, must be imposed upon the individual" (Nietzsche, the will to power 390).The excessive longing for peace, equality, and freedom is hence no more than a dream, and even if it was realised it would never endure:

"There was something called liberalism. Parliament, if you know what that was, passed a law against it. The records survive. Speeches about liberty of the subject. Liberty to be inefficient and miserable. Freedom to be a round peg in a square hole.”(Huxley, Brave New World 34) This idea of the emergence of the illusory liberty is being expressed even more boldly in the world of Nineteen Eighty Four:

The idea of an earthly paradise in which men should live together in a state of brotherhood, without laws and without brute labour, had haunted the human imagination for thousands years (Orwell, Nineteen Eighty Four 142) 
DOI: https://doi.org/10.24113/ijohmn.v6i1.165

To emphasise, George Orwell writes in Homage to Catalonia:

The thing that attracts ordinary men to socialism and makes them willing to risk their skins for it, the 'mystique' of socialism, is the idea of equality; to the vast majority of people socialism means a classless society, or it means nothing at all (p83)

Because, this idea is the ultimate purpose of their lives the success of reaching it, is not something impossible to achieve, however, the problem lies on the fact of misusing it. In other words, the problem becomes bigger as this utopian consideration of life turn to be no more than a fallacy. In this light, the revolution from which I have thrusted its mystery is nothing more than a means from which a dictatorship is established and kept prevailing ceaselessly. To be sure, "power is not a means it is an end" (Orwell, Nineteen Eighty Four 185). Nietzsche states that power is maintained "by the fact that many generations sacrifice themselves for it" (Nietzsche, The Will to Power 390). More peculiarly, the ruling masses actually sacrifice their human nature and decency for the sake of power; this will ultimately lead to their degradation. Furthermore, Nietzsche pictures in his book The Will to Power this profound instinct that does not cease from demanding. Forever Man wants more and more because "one desires freedom, so long as one does not possess power. Once one does possess it, one desires to overpower" (Nietzsche 412)

In the world of Nineteen Eighty Four, "the world where nothing is yours own except the few cubic centimeters inside your skull” (Orwell, Nineteen Eighty Four 18), the world where inequality has become "the unalterable law of the human life" (Orwell, Nineteen Eighty Four 141), The masses who are narcotic with the idea of equality and freedom, theyare in turn doomed to become hollow and staffed with lies instead of all what is human. The party considers the sense of humanity, decency, intellectuality and sanity as the real danger.In the world of Nineteen Eighty Four the masses are formed and shaped, indeed "everyone is washed clean" (Orwell, Nineteen Eighty Four 179) deprived of any kind of intellect and critical 
DOI: https://doi.org/10.24113/ijohmn.v6i1.165

thought. Still, they expose a certain danger over the party which is only theoretical. Because for the party they are voiceless and too ignorant to even think of standing against the party: The masses never revolt of their own accord, and they near revolt merely because they are oppressed .Indeed, so long as they are not permitted to have standards of comparison, they never even become aware that they are oppressed. The recurrent economic crises of past times were totally unnecessary and are not now permitted to happen, but other and equally large dislocations can and do happen without having political results, because there is no way in which discontent can become articulate (Orwell, Nineteen Eighty Four 144)

From this quote in particular I shall raise the main difference that marks the distance in style between Nineteen Eighty Four and Brave New World. For in Nineteen Eighty Four, the masses are sunk into an eternal docility, they are conditioned through a tremendous fear and agony that the party and more peculiarly Big Brother fuses on them.

In Brave New World the masses are not conditioned by fear and this render the matter even more dangerous than it appears to be, the masses' consent and contentedness are very well manufactured. To put it differently, they are blindly convinced that all what matters intheir lives is the fact of having a perpetual happiness and pleasure and of course to every aspect in life there must be a price to be paid for, the price assuredly would lie on the human consciousness of a horrible reality veiled with immeasurable lies and falsifications:

People were ready to have even their appetites controlled then. Anything for a quiet life. We've gone on controlling ever since. It hasn't been very good for truth, of course. But it's been very good for happiness. One can't have something for nothing. Happiness has got to be paid for. (Huxley, Brave New World 156)

Conclusion

Nineteen Eighty Four and Brave New World are, then, about political "violence" (by mentioning the word "violence" I mean both the concrete violence as perceived in Nineteen 
DOI: https://doi.org/10.24113/ijohmn.v6i1.165

Eighty Four and the abstract violence that is perceived in Brave New World). These visionary masterpieces can with their simplistic yet powerful style transcend the future generations. For, they have succeeded effectively to live for the world of today and the world of tomorrow. These keen dystopian pictures that both writers George Orwell and Aldus Huxley each in his own manner have attempted to draw in the time when they lived seems to become truer in our contemporary technological age. We are indeed conditioned by an outer power that makes us consciously or unconsciously abide by its scientific and technological creations which in turn serve to the greatest extent its political purposes. What I attempt to delineate in this paper is the warnings these visionary writers have attempted to employ. These writers' vision states that the war the future generations are going to go through is no longer meant to take their lives for the sake of expanding their territories and their wealth by a mere industrial revolution, weapons, and atomic bombs. But rather this is a war that is meant to destroy all what may provide the masses with their true identity, maintain their individuality, and authenticates their common sense.

I would finally say that Nineteen Eight Four and Brave New World would complete each other if we put a deep eye into what is happening in our actual world. Exceptionally, the slogan "BIG BROTHER IS WATCHING YOU" has overwhelmed the atmosphere of our political age. It denotes shades of complex meanings.

Today, BIG Brother stands hand in hand with the sciences and the numerical technologies. The Big Brother of today has a tremendous authority over the people. This peculiar authority of continuously "WATCHING" the people in all aspects of their lives, and penetrating into their private lives make their world like a prison. With a deep eye into the world of today, this prison situation is becoming more and more real. The modern surveillance network has made the world consequently shrink.. 
DOI: https://doi.org/10.24113/ijohmn.v6i1.165

Bibliography

Primary Sources:

Huxley, Aldus. Brave New World. London, 1932.

Nietzsche, Friedrich. The Will to Power. Ed. Walter Kaufmann. Trans. Walter Kaufmann and R.J.Hdlingdale. New York: AVintage Giant Books, 1968.

Orwell, George. Homage to Catalonia. 1938.

-. Homage to Catalonia. 1938.

—. Nineteen Eighty Four. England, 1949. 